Öğretmen Adayları için FeTeMM Eğitimi Hakkında Öz yeterlik ve Endişe Ölçeğinin Türkçeye Uyarlama Çalışması

Güney Haciömeroğlu

Matematik ve Fen Bilimleri Eğitimi Bölümü, Eğitim Fakültesi, Çanakkale Onsekiz Mart Üniversitesi, Çanakkale, Türkiye

Sorumlu Yazar: Güney Haciömeroğlu, hguney@comu.edu.tr

Makale Türü: Araştırma Makalesi

Kaynak Gösterimi: Hacıömeroğlu, G. (2020). Öğretmen Adayları için FeTeMM Eğitimi Hakkında Öz yeterlik ve Endişe Ölçeğinin Türkçeye uyarlama çalışması. Eğitimde Kuram ve Uygulama, 16(2), 165-177. doi: 10.17244/eku.788985

Turkish Adaptation Study of the Instrument of Self-efficacy and Concerns about STEM Education for Pre-service

Teachers

Güney Hacı̈̈meroğlu

Department of Mathematics and Science Education, Faculty of Education, Canakkale Onsekiz Mart University, Canakkale, Turkey

Corresponding Author: Güney Haciömeroğlu, hguney@comu.edu.tr

Article Type: Research Article

To Cite This Article: Hacıömeroğlu, G. (2020). Öğretmen Adayları için FeTeMM Eğitimi Hakkında Öz yeterlik ve Endişe Ölçeğinin Türkçeye uyarlama çalışması. Eğitimde Kuram ve Uygulama, 16(2), 165-177. doi: 10.17244/eku.788985 


\title{
Öğretmen Adayları için FeTeMM Eğitimi Hakkında Öz yeterlik ve Endişe Ölçeğinin Türkçeye Uyarlama Çalışması
}

\author{
Güney Hacı̈̈meroğlu \\ Matematik ve Fen Bilimleri Eğitimi Bölümü, Eğitim Fakültesi, Çanakkale Onsekiz Mart Üniversitesi, Çanakkale, Türkiye \\ ORCID: https://orcid.org/0000-0002-7562-9976
}

\begin{tabular}{|c|c|}
\hline Öz & Makale Bilgisi \\
\hline $\begin{array}{l}\text { Bu araştırmada Geng, Jong ve Chai (2019) tarafından geliştirilen FeTeMM eğitimi } \\
\text { hakkında öz yeterlik ve endişe ölçeğinin öğretmen adayları için Türkçeye uyarlama } \\
\text { çalışmasının yapılması amaçlanmışır. Ölçek öz yeterlik, endişe olmak üzere iki boyuttan } \\
\text { oluşmaktadır. Endişe düzeyi değerlendirme, bilgi, yönetim, sonuç ve yeniden odaklanma } \\
\text { olmak üzere beş alt boyuttan oluşmaktadır. Ölçeğin geçerlik ve güvenirlik çalışmaları } \\
\text { kapsamında açımlayıcı faktör analizi, test tekrar test, doğrulayıcı faktör analizi yapıllmıştır. } \\
\text { Elde edilen sonuçlar, uyarlanan ölçeğin özgün halinden farklı bir yapı oluşturduğunu } \\
\text { ortaya koymuştur. Uyarlanan ölçek, öz yeterlik }(\alpha=.86) \text {, bilgi ve değerlendirme }(\alpha=.90) \text {, } \\
\text { yönetim ( } \alpha=.86) \text {, sonuç ve yeniden odaklanma }(\alpha=.83) \text { olmak üzere dört alt boyuttan } \\
\text { oluşmaktadır. Ölçeğin bütünü için güvenirlik katsayısı .94 olarak hesaplanmıştır. } \\
\text { Açımlayıcı faktör analizi sonunda ortaya çıkan yapının uygunluğunu test etmek amacıyla } \\
\text { yapılan doğrulayıcı faktör analizi sonuçları ortaya çıkan modelin kabul edilebilir düzeyde } \\
\text { uyum gösterdiğini ortaya koymuştur. Uyarlanan ölçek geçerli ve güvenilir bir ölçme } \\
\text { aracıdır. }\end{array}$ & $\begin{array}{l}\text { Makale Geçmişi: } \\
\text { Geliş: } 1 \text { Eylül } 2020 \\
\text { Düzeltme: } 25 \text { Ekim } 2020 \\
\text { Kabul: } 9 \text { Kasım } 2020\end{array}$ \\
\hline
\end{tabular}

\section{Turkish Adaptation Study of the Instrument of Self-efficacy and Concerns about STEM Education}

\section{for Pre-service Teachers}

\begin{abstract}
Purpose of this research study was to adapt the instrument called 'Self-efficacy and concerns about STEM education' developed by Geng, Jong, and Chai (2019) for preservice teachers into Turkish. This instrument includes two sub-scales: self-efficacy and stages of concerns. In order to measure the stages of concern, the instrument was designed by five sub-dimensions: evaluation, information, management, consequence and refocusing. For the reliability and validity of the study, exploratory factor analysis, testretest and confirmatory factor analysis were applied. Results of the analysis revealed that adapted instrument had different factor loading in comparison to original instrument. The Cronbach's alpha coefficients were calculated as .94 for the instrument. For the subscales, self-efficacy, information and evaluation, management, consequence and refocusing reliability coefficient was calculated as $.86, .90, .86$ and .83 , respectively. Confirmatory factor analysis was conducted to examine to what extend the model was acceptable. Results of the confirmatory factor analysis revealed that the model was acceptable. Adapted instrument was valid and reliable to use.
\end{abstract}

\section{Article Info}

Keywords: Concern, Preservice teacher, Self-efficacy, STEM education

\section{Article History:}

Received: 1 September 2020

Revised: 25 October 2020

Accepted: 9 November 2020

Article Type: Research Article

Not: Bu çalışmada, veri toplama sürecine geçilmeden Çanakkale Onsekiz Mart Üniversitesi’nden 21.05.2020 tarih ve 2020/94 sayıl1 etik onay alınmıştır. 


\section{Extended Summary}

Purpose of this research study was to adapt the instrument called 'Teachers' self-efficacy and concerns about STEM education' developed by Geng, Jong, and Chai (2019) for pre-service teachers into Turkish. For the reliability and validity of the instrument process, data was gathered from pre-service teachers majoring at elementary teacher education programs. Sample consists of $3^{\text {rd }}$ and $4^{\text {th }}$ year pre-service teachers. For the sampling, elementary pre-service teachers were selected since these teachers are going to be the most effective STEM teachers in K through 12 grades. Elementary teachers are defined as generalist. In other words, they are expected to teach subjects such as mathematics, science, social studies. Therefore, it is essential to have an instrument to determine elementary pre-service teachers' self-efficacy and concern about STEM education.

In this research study, the instrument developed by Geng and colleagues (2019) was selected for the Turkish adaptation. This instrument involves two sub-scales: self-efficacy and stages of concerns. In order to measure the stages of concern, the instrument was designed by five sub-dimensions: evaluation, information, management, consequence and refocusing. For the reliability and validity of the study, exploratory factor analysis, test-retest and confirmatory factor analysis were applied. At first the instrument was translated to Turkish by the researcher. At the same time, a group of experts involving 5 people (two in mathematics education, 2 in teacher education and one in English language teaching) translated instrument into Turkish language. Both translations completed independently by the group of experts and researcher. Then, these translations were brought together and analyzed by their common and differing aspects. Final version of the items in the instrument was examined by a Turkish language education expert in terms of the compatibility of Turkish written expression and grammar. A final version of the self-efficacy and concern about STEM education instrument was prepared for the pre-service teachers.

In this study, sample consists of pre-service teachers majoring elementary teacher education program at a public university in Marmara region. Sample included $3^{\text {rd }}$ and $4^{\text {th }}$ year elementary pre-service teachers. After receiving the necessary scientific research and ethics committee permissions, 215 (43 male and 172 female) pre-service teachers volunteered to participate in the research study. For the test and re-test reliability study, 45 (17 male and 18 female) pre-service teachers were participated. The instrument includes 25 items. Research suggested that the sample should be between 5 to 10 times of the number of items.

In this study, the instrument includes 25 items. Accordingly, the sample of the research $(n=215)$ is suitable for the adaptation study. The 25 items of the Self-efficacy and Concern about STEM education Instrument were subjected to exploratory analysis (EFA) using SPSS version 25. The Kaiser- Meyer-Olkin value was .923 and the Bartlett's Test of Sphericity reached statistical significance $\left(X^{2}{ }_{(300)}=3147.269, \mathrm{p}=.000 \mathrm{p}<.01\right)$, supporting the factorability of the correlation matrix. The result of the analysis showed that the data was adequate for factor analysis. EFA revealed the presence of four components with eigenvalues exceeding 1, explaining $61.664 \%$ of the variance, respectively. Varimax rotation was conducted for the interpretation of the component. The rotated solution revealed all variables loading substantially on four components.

Results of the analysis revealed that adapted instrument had different factor loading in comparison to original instrument. The original instrument includes five sub-scales: self-efficacy, information, evaluation, management, and consequence and refocusing. For the original scale, the Cronbach's alpha coefficients were calculated as $.92,78, .83$, $.81, .72$ ve .70 respectively. The Cronbach's alpha coefficients for the whole scale were calculated as .94 for the adapted instrument. Adapted version of the instrument two sub-scales information and evaluation was merged. As a result, adapted instrument includes four sub-scales: self-efficacy, information and evaluation, management, consequence and refocusing. For the sub-scales, self-efficacy, information and evaluation, management, consequence and refocusing reliability coefficient was calculated as $.86, .90, .86$ and .83 , respectively.

The reason for why the original and adapted instrument's factor loading was different might be related to culture and participants. In the development of the original instrument, data was gathered from Taiwanese in-service teachers. In this study data was collected from Turkish pre-service teachers. Having inexperience regarding teaching STEM subjects in Turkish cultural setting might be the reason why the structure of the adapted instrument was different. Confirmatory factor analysis was conducted to examine to what extend the model was acceptable. Results of the confirmatory factor analysis revealed that the model was acceptable. Adapted instrument was valid and reliable to use in Turkish culture. As a further research, an adaptation study of the instrument can be carried out to examine the selfefficacy and concern about STEM education of pre-service teachers within the scope of STEM applications for Science, Technology Engineering and Mathematics-Arts (STEM-S) and social sciences. In addition, within the scope of STEM education, a study of Turkish adaptation of the instrument could be conducted with in-service teachers (classroom, science, mathematics, etc.) to examine their self-efficacy and concern about STEM education. 


\section{Giriş}

Öğretmen adaylarının etkili birer FeTeMM öğretmeni olarak hizmet içi eğitimde görev almalarında öğretime yönelik öz yeterlikleri ile endişe düzeyleri önemli bir rol oynamaktadır. Disiplinler arası FeTeMM eğitimi uygulamalarında anlamlı öğrenmenin gerçekleştirilmesinde, öğrencilerin ihtiyaçlarını belirleme ve karşılama hususlarında adayların yüksek öz yeterliğe sahip olması önemlidir. Araştırmalar (Tschannen-Moran \& Hoy, 2007; Tschannen-Moran, Woolfolk-Hoy, \& Hoy, 1998; Usher \& Pajares, 2008) yüksek öz yeterliğe sahip öğretmenlerin, öğrencilerin tam potansiyellerine ulaşmalarında önemli bir yere sahip olduğunu vurgularken düşük öz yeterliğe sahip öğretmenlerin öğrencilerin öğrenmeye yönelik ihtiyaçlarını karşılamada yetersiz kaldığını belirtmektedir. Benzer şekilde, araștırmalar (Fuller, 1969; Gene, George, \& Stiegelbauer, 2013) öğretmen adaylarının öğretmeye yönelik endişelerinin kendilerini öğretime yönelik yetersiz hissetme ve öğretime yönelik bilgilerinden şüphe duyma şeklinde ortaya çıktığını vurgulamaktadır. Bu durum, nitelikli bir öğretim için öğretmen yetiştirme sürecinde adayların öz yeterliklerinin geliştirilmesinin ve öğretime yönelik endişelerinin giderilmesinin ne kadar önemli olduğunu ortaya koymaktadır. Araştırmalar incelendiğinde farklı alanlara (fen bilgisi, kimya öğretmenliği, sınıf eğitimi, matematik eğitimi) yönelik öğretmen adaylarının öz yeterlik (Güven \& Akçay, 2012; Pul \& Aksu, 2020; Timur \& Belek, 2020) ve endişe (Anılan, Görgülü, \& Balbă̆, 2009; Dinçer \& Bıkmaz, 2020; Seçkin \& Yılmaz, 2014) düzeylerinin birbirlerinden bağımsız olarak ele alınarak incelendiği görülmektedir. Bu durum öğretmen adaylarının FeTeMM öğretimine yönelik öz yeterlik ve endişe düzeylerini belirmek amacıyla kullanılabilecek bir ölçme aracına olan ihtiyacı ortaya koymuştur.

\section{Öz yeterlik}

Öz yeterlik "bireyin belli bir performansı göstermek için gerekli etkinlikleri organize edip başarılı olarak yapma kapasitesine ilişkin kendi yargısı" (Bandura, 1986, p. 391) olarak ifade edilmektedir. Öz yeterlik bireyin nitelikli ve etkili bir öğretmen olmasında önemli bir role sahiptir. Pendergast, Garvis ve Keogh (2011) öz yeterliği yüksek olan öğretmenlerin öğrencilerin tam potansiyellerine ulaşmaları için daha fazla çaba sarf ederek yardımcı olduğunu vurgulamaktadır. Ancak, öz yeterlikleri düşük olan öğretmenler öğrencilerin öğrenmeye yönelik ihtiyaçlarını karşılamada yetersiz kalmaktadır. Bu sebeple, hizmet öncesi dönemde öğretmen adaylarının öz yeterliklerinin belirlenmesi ve incelenmesi gelecekte yapacakları uygulamalar açısından önem taşımaktadır. Tschannen-Moran ve Woolfolk-Hoy (2001) bireylerin öz yeterlik gelişimleri desteklendiğinde etkili, kendisini mesleğine adayan ve istekli öğretmenler yetiştirildiğini vurgulamaktadır. Öğretmen öz yeterliği kişisel deneyimler, dolaylı yaşantılar, sözel ikna ve psikolojik durumlar olmak üzere dört kaynağa bağlı olarak açıklanmaktadır.

\section{Kişisel deneyimler}

Kişisel deneyimler bireyin öğretime ilişkin performansları hakkında net sonuçlar ortaya koyması sebebiyle en etkili öz yeterlik kaynağı olarak gösterilmektedir (Bandura, 1997; Mulholland \& Wallace, 2001; Usher \& Pajares, 2008). Bireyin öğretime ilişkin başarılı performansları öz yeterliğine olumlu bir artış olarak yansırken başarısızlıkları ise öz yeterliğinde düşüşe sebep olmaktadır. Bir öğretmenin kişisel deneyimlerine bağlı olarak öz yeterliğinin gelişimi geçmişte edindiği başarılı ve başarısız deneyimlere bağlı olarak gerçekleşmektedir (Tschannen-Moran, Woolfolk-Hoy \& Hoy, 1998). Bir başka deyişle, birey geçmişte edindiği deneyimlerde başarılı olduğunu düşünüyor ise benzer bir problem durumuyla karşılaştı̆̆ında bu duruma öz güvenle yaklaşır. Ancak, birey edindiği deneyimde başarısız olduğunda konuya ilişkin becerilerinin yetersiz olduğunu düşünmektedir (Usher \& Pajares, 2008).

\section{Dolaylı Yaşantılar}

Birey yeterlik inancını dolaylı yaşantılar yoluyla başkalarını (akran, rol model, ebeveyn vb.) gözlemleyerek oluşturmaktadır. Problem durumunun zorluğu karşısında zorluk çektiğini gösteren ve başarılı olan rol modeli, bireyin öz yeterliğinin olumlu yönde gelişmesinden önemli bir rol oynamaktadır (Kitsantas, Zimmerman, \& Cleary, 2000; Morris, Usher, \& Chen, 2017; Schunk \& Hanson, 1989). Bu durum, bireyin kendi performanslarını rol modeli aldığ 1 kişinin performanslarıyla karşılaştırma fırsatı sunmaktadır (Bandura, 1986; 1991).

\section{Sözel İkna}

Bireyin güvendiği, bilgili kişiler (öğretmenler, akranlar, vb.) tarafından değerlendirmeye yönelik ifade edilen cesaretlendirici sözler kendilerine olan güvenlerini artırır. Ancak sözel ikna söz konusu olduğunda dönüt veren bu kişilerin bilgili ve güvenilir oluşu çok önemlidir. Bu şekilde verilen mesajlar bireyin öz yeterlik inancının gelişimi üzerinde güçlü bir etki bırakmaktadır (Hattie \& Timperley, 2007; Schunk, 1984). Ancak, cesaret kırıcı mesajlar bireyin yeterlik inancına önemli derecede zarar vermektedir. Özellikle bireyin konuya ilişkin deneyimi sınırlı olduğunda verilen olumlu ve olumsuz mesajların çok güçlü bir etkisinin olduğu vurgulanmaktadır (Bandura, 1997).

\section{Psikolojik Durumlar}

Birey içinde bulunduğu durumu değerlendirirken stres, bitkinlik, kaygı gibi fizyolojik ve duygu durumlarına bağlı olarak durumu değerlendirir. Birey fiziksel ve duygusal olarak kendini iyi hissettiğinde ve olumsuz duygusal durumlar 
azaltıldığında öz yeterlik güçlenmektedir. Başarılı bir ders anlattığında bireyin hissettiğgi mutluluk öz yeterliğini olumlu yönde etkilemektedir. Ancak, birey ders anlatırken stresli veya kaygılı olduğunda sinıfın kontrolünü kaybedeceğine dair korku hissettiğinde bu durum öz yeterliği olumsuz yönde etkilemektedir (Tschannen-Moran \& Hoy, 2007). Öğretime ilişkin kendisine güvenen bireylerin öğretim sürecinde yaptıkları hatalardan ders alma eğilimlerinin daha fazla olduğu vurgulanmaktadır (Bandura, 1997). Araştırmalar öğretmen öz yeterliğinin öğretmen yetiştirme programlarında öğrenim görürken arttığını (Hoy \& Woolfolk, 1990; Wenner, 2001) ancak mezun olup göreve başladıktan bir yıl içerisinde azaldığını vurgulamaktadır (Moseley, Reinke, \& Bookour, 2003; Woolfolk-Hoy, 2000).

\section{Endișe}

Endişe bireyin hislerinin, zihnini meşgul eden düşüncelerinin ve dikkate aldığ durum ve görevlerin birleşik temsili olarak tanımlanmaktadır (Newlove \& Hall, 1976). Öğretim için bu durum Fuller (1969) tarafindan bireyin endişe düzeyinin kendisiyle ilgili endişeden, öğretim uygulamalarına yönelik endişeye ve daha sonrasında ise öğretimin öğrenciler üzerindeki etkisi şeklinde ilerleyen bir süreç olarak gösterilmektedir. Fuller (1969) ile Gene ve diğerleri (2013) öğretmen adayı ve öğretmen olarak bireylerin öğretime yönelik endişelerini sürece göre sinıflandırmıştır. Öğretmen yetiştirme programlarında öğrenim gören adaylarının eğitimlerinin başlangıcında, öğretime ilişkin hiçbir deneyimi olmadığı için endişe duygusundan yoksun olduğu vurgulanmaktadır. Adayların sınavda başarılı olmak veya uyumlu olabilmek gibi endişelere sahip olduğu belirtilmektedir. Öğretmen eğitiminin ilerleyen aşamalarında ise kendisini öğretime ilişkin yetersiz hissetme veya kendi bilgisinden şüphe etme şeklinde ortaya çıkmaktadır. Hizmet içi eğitimde yeni görev alan öğretmenlerin ise öğretime ilişkin materyallerin hazırlanması, planlaması gibi görev odaklı endişeleri olduğu belirtilmektedir. Deneyimli öğretmenlerin ise öğretimlerinin öğrencilerin öğrenmeleri ve başarıları üzerindeki etkisi ile bir öğretmen olarak kendilerini nasıl geliştirebileceklerine yönelik endişelerinin olduğu vurgulanmaktadır (Fuller, 1969; Gene et al., 2013).

Hall ve diğerlerinin (1977) çalışmasından yola çıkarak Cheung (2002) ile Cheung, Hattie ve $\mathrm{Ng}$ (2001) tarafından yapılan çalışma, endişe düzeylerinin beş aşamalı (değerlendirme, bilgi, yönetim, sonuç ve yeniden odaklanma) bir model olduğunu belirlemiştir. Bu araştırmada, Türkçeye uyarlama çalışması yapılan ölçme aracı geliştirilirken Cheung (2002) ile Cheung ve diğerleri (2001) tarafından geliştirilen model temel alınmıştır. Geng, Jong ve Chai (2019) FeTeMM Eğitimi Hakkındaki Endişe boyutlarını oluştururken bu modeli kullanmıştır. Bu modele göre FeTeMM eğitimine ilişkin olarak değerlendirme, bilgi, yönetim, sonuç ve yeniden odaklanma endişe düzeyleri yeniden tanımlanmıştır. Değerlendirme adımı aracılığı ile öğretmen adaylarının faydalı eğitim uygulamalarını sınıflarında kullanmaya yönelik endişelerinin belirlenmesini içermektedir. Bilgi aracılı̆̆ı ile öğretmen adaylarının yapacakları uygulamalarda sahip olmaları gereken bilgi, destek ve kaynaklara ilişkin endişe düzeylerinin ortaya konulmasını hedeflemektedir. Yönetim ise öğretmen adaylarının FeTeMM eğitiminde öğretim uygulamalarının yönetimi ve organizasyonuna ilişkin endişe düzeylerinin belirlenmesini amaçlamaktadır. Sonuç ise öğretmen adaylarının öğretime ilişkin kullanılan kaynakların öğrencilerin öğrenme deneyimleri üzerindeki etkisini ortaya koymak amacıyla kullanılmaktadır. Yeniden odaklanma aşaması ise öğretmen adaylarının FeTeMM eğitiminde kullanılan yaklaşımları geliştirmeye yönelik var olan endişelerini belirlemeyi amaçlamaktadır (Geng et al., 2019).

\section{Öğretmen Adayları için Geçerlik ve Güvenirlik Çalışması Yapılan Ölçme Araçları}

Fen, Teknoloji, Mühendislik ve Matematik disiplinlerinin en az ikisi ve/veya tamamının entegre edilerek yapılan öğretim uygulamaları kısaca FeTeMM olarak isimlendirilmiştir. Ülkemizde son yıllarda, FeTeMM eğitimine yönelik birçok çalışma yapılmaktadır. Bu çalışmalar öğrencilerin, öğretmenlerin ve öğretmen adaylarının FeTeMM eğitimine yönelik deneyimlerini ve görüşlerini ortaya koymakla beraber öz yeterlik, tutum ve inanç gibi duyuşsal özelliklerini incelemektedir (Canbazoğlu \& Tümkaya, 2020; Çevik, 2018; İnançlı \& Timur, 2018; Hacıömeroğlu, 2018). Buna ek olarak, yapılan bazı çalışmalarda ise bireylerin FeTeMM eğitimine ilişkin deneyimlerini ve görüşlerini ortaya koymak üzere ölçme araçlarının geçerlik ve güvenirlik çalışmalarının yapıldığı görülmektedir.

Ulusal düzeyde FeTeMM eğitimi kapsamında öğretmen adaylarının görüşlerini ortaya koymak amacıyla farklı ölçme araçlarının geliştirildiği ve uyarlandığı görülmektedir. Araştırmalar incelendiğinde öğretmen adaylarının FeTeMM eğitimi kapsamında anlamsal algılarını (Kızılay, 2017), öğretim yönelimlerini (Hacıömeroğlu \& Bulut, 2016), farkındalık düzeylerini (Buyruk \& Korkmaz, 2016), tutumlarını (Derin, Aydın, \& Kırkıç, 2017), öz yeterlik düzeylerini (Gelen, Akçay, Tiryaki, \& Benek, 2019; Yaman, Özdemir, Akar, \& Vural, 2018) incelemek amaciyla ölçme araçlarının geçerlik ve güvenirlik çalışmalarının yapıldığı görülmektedir. Kızılay (2017) öğretmen adaylarının FeTeMM alanlarına yönelik anlamsal algılarını belirlemek amacıyla Knezek ve Christensen (2008) tarafindan geliştirilen ‘STEM Semantik Farklılık Ölçeğini’ Türkçeye uyarlamıştır. Uyarlanan ölçeğin fen, teknoloji, mühendislik, matematik ve kariyer olmak üzere beş alt boyuttan oluştuğu belirlenmiştir. Uyarlanan ölçek 25 maddeden oluşmaktadır. Alt faktörler için hesaplanan Cronbach alfa güvenirlik katsayı değerleri sırasıyla .91, .84, .86, .92 ve $.87^{\prime}$ dir. Ölçeğin bütünü için bu değer .82 olarak hesaplanmıştır. Hacıömeroğlu ve Bulut (2016) tarafindan yapılan çalışmada Lin ve Williams (2016) tarafindan geliştirilen 'Entegre FeTeMM Öğretimi Yönelim Ölçeği' Türkçeye 
uyarlanmıştır. Bu ölçme aracı öğretmen adaylarının entegre FeTeMM öğretimine ilişkin yönelimlerini belirlemek amacıyla Türk kültürüne kazandırılmıştır. Uyarlanan bu ölçek beş alt boyuttan (bilgi, değer, tutum, sübjektif ölçüt, algılanan davranış kontrolü ve davranış yönelimi) oluşmaktadır. Alt boyutlar için güvenirlik katsayısı sırasıyla $.93, .86, .87, .69$ ve .86 olarak hesaplanmıştır. Uyarlanan ölçekte 31 madde yer almaktadır ve 7'li Likert tipindedir. Buyruk ve Korkmaz (2016) ise öğretmen adaylarının FeTeMM eğitimi konusundaki farkındalık düzeylerini belirlemek amacıyla 'FeTeMM Farkındalık Ölçeğini' geliştirmiştir. Geliştirilen ölçek 5'li Likert tipindedir ve 17 maddeden oluşmaktadır. Ölçek, olumlu bakış ve olumsuz bakış olmak üzere iki alt boyuttan oluşmaktadır. Bu alt boyutlar için hesaplanan güvenirlik katsayısı sırasıyla .92 ve .80 'dir. Ölçeğin bütünü için hesaplanan Cronbach alfa güvenirlik katsayıs1 .92'dir. Derin ve diğerleri (2017) ise Berlin ve White (2020) tarafından geliştirilen öğretmen adayları için FeTeMM eğitimi tutum ölçeğini Türkçeye uyarlamıştır. Ölçek 32 maddeden oluşmaktadır. Geliştirilen ölçek anlamlılık ve yapılabilirlik olmak üzere iki alt boyuttan oluşmaktadır. Alt boyutlar için Cronbach alfa güvenirlik katsayıları sırasıyla .92 ve .84 olarak hesaplanmıştır. Ölçeğin tümü için bu değer .77 olarak belirlenmiştir.

Yapılan iki çalışmada ise FeTeMM eğitimine yönelik olarak öğretmen adaylarının öz yeterlik düzeylerini belirlemeye yönelik ölçme araçlarının kazandırıldığı görülmektedir. Yaman ve diğerleri (2018) tarafından yapılan çalışmada FeTeMM uygulamalarına iliş̧in olarak öğretmen adaylarının öz yeterlik düzeylerini belirlemek amacıyla bir ölçme aracı geliştirilmiştir. Geliştirilen ölçek tek boyutludur. Ölçek 5'li Likert tipindedir ve 18 maddeden oluşmaktadır. Ölçek için hesaplanan güvenirlik katsayısı .97'dir. Benzer şekilde, Gelen ve diğerleri (2019) tarafından yapılan çalışmada Friday Institute for Educational Innovation tarafından geliştirilen ölçme aracı 'Fen Bilimleri Öğretmen Adaylarının Fen-Teknoloji-Mühendislik-Matematik (FeTeMM)'e Yönelik Özyeterlik Ölçeği' olarak Türkçeye uyarlanmıştır. Uyarlanan ölçek 5'li Likert tipindedir ve 12 maddeden oluşmaktadır. Ölçek iki alt boyuttan (fen bilimleri öğretiminde öz yeterlik inancı ve fen bilimleri öğretimi sonucu beklentileri) oluşmaktadır. Alt boyutlar için güvenirlik katsayıları sırasıyla .84 ve .79 olarak hesaplanmıştır. Ölçeğin bütünü için hesaplanan Cronbach alfa güvenirlik katsayısı .80 'dir. Ulusal düzeyde yapılan araştırmalar incelendiğinde öğretmen adaylarının öz yeterlik düzeylerini incelemeye yönelik iki ölçme aracının alan yazına kazandırıldığı görülmektedir. FeTeMM eğitimi söz konusu olduğunda öğretmen adaylarının belirli bir performansı yerine getirebilme ve başarılı olmaya ilişkin inançlarını yani öz yeterlikleri ölçmek gelecekte yapacakları uygulamalar açısından önemli bir yer tutmaktadır. Ancak, FeTeMM eğitiminde en az iki disiplinin bir araya getirilerek oluşturulan etkinlerin uygulamaları söz konusu olduğunda öğretmen adaylarının bu hususa ilişkin endişe düzeylerini belirlemek hizmet öncesi eğitimde önemli bir yer tutmaktadır. Adayların FeTeMM eğitimine yönelik uygulamalar söz konusu olduğunda hangi hususlarda öğretmen adaylarının endişe duyduklarını belirlemek etkinliklerin tasarlanması, uygulanması ve değerlendirilmesi açısından faydalı olacaktır. Bu şekilde, öğretmen adayları gelecekte bir öğretmen olarak nitelikli FeTeMM eğitimi odaklı uygulamalar gerçekleştirebilir.

Araştırmalar, öğretime ilişkin yüksek öz yeterliğe sahip öğretmenlerin yenilikçi uygulamalanı adapte edip kullanmaya daha açık olduklarını ortaya koymuştur (Charalambous \& Philippou, 2010; Smith, Corkery, Buckley, \& Calvert, 2012; Tschannen-Moran \& Woolfolk-Hoy, 2001). Yüksek öz yeterliğe sahip öğretmenlerin öğrenciler üzerinde bıraktıkları etki hususunda endişeli oldukları görülürken (McKinney, Sexton, \& Meyerson, 1999) düşük öz yeterliğe sahip öğretmenlerin ise görev odaklı endişelerinin yüksek olduğu (Ghaith \& Shaaban, 1999) belirlenmiştir. $\mathrm{Bu}$ araştırma sonuçlarından hareketle, öğretmen adaylarının bir öğretmen olarak görev yapmaya başlamadan önce öz yeterliklerini belirlemeye, geliştirmeye yönelik çalışmaların yapılması gelecekte yapacakları uygulamalar açısından önem taşımaktadır. Yüksek öz yeterlik öğretmen adaylarının gelecekte öğrencilerinin öğrenmelerini desteklemeleri ve yapacakları uygulamalara güvenle ve kararlı bir şekilde yaklaşmaları açısından önemlidir (Hao \& Lee, 2016). Öz yeterlik, bireyin endişe düzeylerini etkileyen önemli faktörlerden bir tanesi olarak gösterilmektedir (Charalambous \& Philippou, 2010). Araştırmalar, öğretmenlerin öz yeterlik ve endişe düzeyleri arasında anlamlı bir ilişki olduğunu ortaya koymaktadır (Cocca, Cocca, Castro, 2017, akt. Geng et al., 2019; Ghaith, \& Shaaban, 1999, Montgomery, \& Mirenda, 2014). FeTeMM eğitiminin öğretimde kullanımına ilişkin öğretmen adaylarının öz yeterlik ve endişe düzeylerinin belirlenmesi gelecekte yapacakları uygulamalar ve bu uygulamaların niteliği açısından önemli bir yere sahiptir. FeTeMM eğitimi alanında geliştirilen ve uyarlanan ölçme araçlarının incelenmesi, öğretmen adaylarının FeTeMM eğitimine yönelik öz yeterlik ve endişe düzeylerini incelemeye yönelik bir ölçme aracına olan ihtiyacı ortaya koymuştur.

\section{Amac}

$\mathrm{Bu}$ araştırma Geng ve diğerleri (2019) tarafından geliştirilen FeTeMM Eğitimi Hakkında Öz Yeterlik ve Endişe Ölçeğinin öğretmen adayları için Türkçeye uyarlama çalışmasının yapılmasını amaçlamaktadır. Bu kapsamda aşağıdaki araştırma sorusuna cevap aranmıştır:

1. Öğretmen adayları için Türkçeye uyarlama çalışması yapılan FeTeMM Eğitimi Hakkındaki Öz Yeterlik ve Endişe Ölçeği geçerli ve güvenilir bir ölçme aracı mıdır? 


\section{Yöntem}

Bu nicel araştırmada Geng ve diğerleri (2019) tarafından geliştirilen Hakkındaki Öz Yeterlik ve Endişe Ölçeğinin öğretmen adayları için Türkçeye uyarlama çalışmasının yapılmasını amaçlamaktadır. $\mathrm{Bu}$ amaç kapsamında bu çalışmada nicel araştırma yöntemlerinden tarama modeli kullanılmıştır (Karasar, 2003).

\section{Çeviri Çalışması}

FeTeMM Eğitimi hakkındaki Öz Yeterlik ve Endişe Ölçeğinde yer alan 25 madde öncelikle araştırmacı tarafından Türkçeye çevrilmiştir. Bununla beraber, beş kişilik bir uzman grubundan (iki matematik eğitimi, iki öğretmen eğitimi, biri İngiliz dili eğitimi) ölçme aracında yer alan 25 maddeyi Türkçeye çevirmeleri talep edilmiştir. Uzman grubundan çevirileri yaparken maddelerin Türkçe halinin özgün haline uygun olarak gerçekleştirmeleri istenmiştir. Araştırmacı ve uzman grubunun birbirlerinden bağımsız olarak yaptıkları çeviriler bir araya getirilerek ortak ve ayrılan yönleri tarafından ele alınarak incelenmiştir. Son hali verilen ölçme aracındaki maddeler Türkçe yazılı anlatım ve dil bilgisi uygunluğu açısından bir Türkçe eğitimi alan uzmanı tarafindan incelenmiştir. Bu şekilde Türkçeye uyarlama çalışmasında kullanılacak öğretmen adayları için FeTeMM hakkındaki öz Yeterlik ve endişe ölçeğinin uygulamaya hazır son hali oluşturulmuştur.

\section{Çalışma Grubu (Katılımcılar)}

$\mathrm{Bu}$ araştırmanın örneklemini Marmara bölgesinde yer alan bir devlet üniversitesinin eğitim fakültesi sınıf eğitimi anabilim dallarında öğrenim gören 3. ve 4. sınıf öğretmen adayları oluşturmaktadır. Güvenirlik çalışması kapsamında veriler 43 erkek ve 172 kız olmak üzere toplam 215 öğretmen adayından toplanmıştır. Geçerlik çalışması kapsamında, test-tekrar test çalışması için ölçek 17 erkek ve $28 \mathrm{k} 1 \mathrm{z}$ olmak üzere toplam 45 öğretmen adayına bir ay arayla uygulanmıştır. Tavşancıl (2002) örneklem büyüklüğünün madde sayısının 5 ile 10 katı arasında olması gerektiğini vurgulamaktadır. Cattel (1978) örneklem büyüklüğünün ölçme aracındaki madde sayısının 3 ile 6 katı arasında olmasının yeterli olacağını belirtirken Hair, Black, Tatham ve Anderson (2010) ise bu değerin madde sayısının 5 katı olması gerektiğini belirtmektedir. Bu çalışmada Türkçeye uyarlama çalışması yapılan ölçme aracında 25 madde yer almaktadır. Buna göre araştırmanın örneklemi $(\mathrm{N}=215)$ madde sayısının 8 katından fazla olması sebebiyle uyarlama çalışması için uygundur.

\section{Çalışmada Kullanılan Ölçme (Veri Toplama) Aracı}

FeTeMM Ĕ̆itimi Hakkında Öz yeterlik ve Endişe Ölçeği: Geng ve diğerleri (2019) tarafindan geliştirilen FeTeMM Eğitimi hakkında Öz Yeterlik ve Endişe Ölçeği 5'li Likert tipinde olup 25 maddeden oluşmaktadır. Bu ölçek öz yeterlik ve endişe olmak üzere iki boyuttan oluşmaktadır. Öz yeterlik boyutunda yer alan maddeler öğretime ilişkin etkinlikler ve sınıf yönetimine odaklanmaktadır. Öz yeterlik boyutu uygulanırken 1-kesinlikle katılmıyorum ile 5kesinlikle katılıyorum ölçek aralıkları kullanılmıştır. Endişe boyutu ise değerlendirme, bilgi, yönetim, sonuç ve yeniden odaklanma olmak üzere beş alt boyuttan oluşmaktadır. Endişeye yönelik maddeler uygulanırken 1-hiç endişeli değilim ile 5-çok endişeliyim ölçek aralıkları kullanılmıştır. Özgün ölçeğin öz yeterlik alt boyutu için hesaplanan güvenirlik katsayısı .92' dir. Diğer alt boyutlar, değerlendirme, bilgi, yönetim, sonuç ve yeniden odaklanma için hesaplanan Cronbach alfa güvenilirlik katsayısı değerleri sırasıyla $.78, .83, .81, .72$ ve .70 olarak belirlenmiştir.

\section{İşlem}

$\mathrm{Bu}$ araştırma kapsamında öncelikli olarak çalışmanın yapılması planlanan eğitim fakültesi dekanlığına bilimsel araştırma faaliyet planı oluşturularak başvuru yapılmıştır. Bu başvuruda çalışmanın amacı, yöntemi, veri toplama araçları gibi hususlarda gerekli bilgiler sunulmuştur. Çalışmanın yürütüleceği eğitim fakültesinden alınan araştırma izniyle beraber aynı üniversitenin Sosyal Bilimler ve Eğitim Bilimleri Etik Kuruluna başvuru yapılarak 21.05.2020 tarih ve 2020/94 protokol numarası ile bilimsel araştırma etik kurallarına uygun olduğuna dair gerekli araştırma izni alınmıştır. Bundan sonraki süreçte araştırma hakkında öğretmen adaylarına bilgi verilmiştir. Gönüllülük esasına göre çalışmaya katılmak isteyen öğretmen adaylarına ölçek uygulanarak veriler toplanmıştır.

\section{Veri Analizi}

Toplanan veriler geçerlik ve güvenirlik çalışmaları kapsamında kullanılmıştır. Bu amaç doğrultusunda faktör analizi, test-tekrar test, doğrulayıcı faktör analizi ve Cronbach alfa güvenilirlik katsayı hesabı yapılmıştır. Bu çalışmada faktör analizi yapılarak uyarlama çalışması yapılan ölçme aracının faktör analizine uygun olup olmadığı belirlenmiştir. Faktör analizi sonucunda ortaya çıkan yapının ne derece uygun olduğunu belirlemek amacıyla doğrulayıcı faktör analizi yapılmıştır. Açımlayıcı faktör analizi için SPSS programı, doğrulayıcı faktör analizi için ise Lisrel programı kullanılmıştır. 
Geçerlik Çalışmasından Elde Edilen Bulgular

\section{Bulgular}

Geçerlik çalışması kapsamında açımlayıcı faktör analizi kullanılarak Kaiser-Meyer-Olkin (KMO) değeri ve Barlett Küresellik Testi hesaplanmıştır. Bu analizler verilerin açımlayıcı faktör analizi için uygun olup olmadığını belirlemek amacıyla kullanılmıştır. Döndürme yöntemi varimax kullanılarak ölçme aracının tek boyutlu olup olmadığına bakılmıştır.

Tablo 1. Açımlayıcı Faktör Analizi Sonuçları

\begin{tabular}{|c|c|c|c|c|c|}
\hline Madde & Öz yeterlik & Bilgi ve değerlendirme & Yönetim & $\begin{array}{l}\text { Sonuç ve yeniden } \\
\text { odaklanma }\end{array}$ & $\mathbf{r}$ \\
\hline 6 & .726 & & & & .565 \\
\hline 5 & .720 & & & & .499 \\
\hline 3 & .690 & & & & .402 \\
\hline 2 & .668 & & & & .592 \\
\hline 4 & .661 & & & & .642 \\
\hline 1 & .607 & & & & .650 \\
\hline 11 & & .735 & & & .647 \\
\hline 12 & & .714 & & & .688 \\
\hline 10 & & .707 & & & .685 \\
\hline 9 & & .704 & & & .674 \\
\hline 8 & & .669 & & & .602 \\
\hline 13 & & .656 & & & .689 \\
\hline 14 & & .536 & & & .629 \\
\hline 7 & & .520 & & & .608 \\
\hline 16 & & & .754 & & .579 \\
\hline 17 & & & .736 & & .616 \\
\hline 18 & & & .694 & & .645 \\
\hline 15 & & & .647 & & .667 \\
\hline 24 & & & & .740 & .346 \\
\hline 21 & & & & .626 & .556 \\
\hline 22 & & & & .622 & .646 \\
\hline 23 & & & & .589 & .687 \\
\hline 25 & & & & .567 & .627 \\
\hline 20 & & & & .540 & .743 \\
\hline 19 & & & & .518 & .718 \\
\hline Cronbach alfa & .86 & .90 & .86 & .83 & .94 \\
\hline
\end{tabular}

Buna ek olarak, uyarlama çalışması yapılan ölçme aracında yer alan maddelerin faktör yük değerleri ve madde toplam test korelasyon değerleri incelenmiştir. Elde edilen bulgular, Kaiser-Meyer-Olkin (KMO) değerinin .923 ve Barlett Küresellik Testi sonuçlarının $X_{(300)}^{2}=3147.269 \mathrm{p}<.01$ şeklinde elde edilmesi sebebiyle verilerin açımlayıcı faktör analizi için uygun olduğu tespit edilmiştir. Yapılan analizler, özdeğeri 1'den büyük dört faktörün olduğunu göstermiştir. Bu faktörlerden birincisi tek başına varyansın \%43.445 açılamaktadır. Dört faktör beraber toplam varyansın \%61.664 açıklamaktadır. Uyarlanan ölçekte yer alan 25 madde için hesaplanan madde toplam test korelasyon değerlerinin “.346-.743” aralığında olduğu belirlenmiştir. Klein (1986) madde toplam test korelasyon değerleri için alt sınırın .20 olması gerektiğini belirtmiştir. Görüldüğü üzere, uyarlama çalışması yapılan ölçekte yer alan maddeler bu sınır değerin üzerinde ve kabul edilebilir aralıktadır (Bakınız Tablo 1).

\section{Güvenilirlik Çalışması Bulguları}

Ölçeğin uyarlama çalışması kapsamında yürütülen test-tekrar test çalışması 45 öğretmen adayı ile yürütülmüş ve bir ay arayla uygulamalar yapılmıştır. Birinci ve ikinci uygulamalara ilişkin ortalama ve standart sapma değerleri

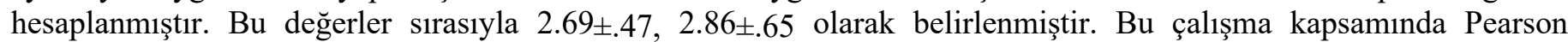
korelasyon katsayıs1 .894, $\mathrm{p}=.001$ olarak hesaplanmıştır. Hesaplanan bu korelasyon katsayısının .000, $\mathrm{p}=.001$ düzeyinde anlamlı olduğu belirlenmiştir. Uyarlanan ölçek öz yeterlik, bilgi ve değerlendirme, yönetim, sonuç ve yeniden odaklanma olmak üzere beş alt boyuttan oluşmaktadır. Uyarlanan ölçeğin özgün haline benzer bir yapı ortaya koyduğu görülmektedir. Ancak, özgün halinden farklı olarak bilgi ve değerlendirme ile sonuç ve yeniden odaklanma alt boyutlarının birleştiği belirlenmiştir. Bu alt boyutlar, öz yeterlik, bilgi ve değerlendirme, yönetim ile sonuç ve yeniden odaklanma için güvenilirlik katsayıları sırasıyla $.86, .90, .86$ ve .83 olarak hesaplanmıştır. Uyarlanan ölçeğin bütünü için hesaplanan Cronbach alfa güvenilirlik katsayıs1 .94 'tür. Öz yeterlik alt boyutunda 1,2,3,4,5,6 maddeleri yer almaktadır. Endişe boyutunu ölçen alt boyutlar, bilgi ve değerlendirme alt boyutunda 7,8,9,10,11,12,13,14 
maddeleri, yönetim alt boyutunda 15,16,17,18, ile sonuç ve yeniden odaklanma alt boyutunda 19, 20,21, 22, 23, 24, 25 maddeleri yer almaktadır (Bakınız Tablo 2).

Tablo 2. Uyarlanan ölçeğe ilişkin boyutlar ve güvenirlik katsayı değerleri

\begin{tabular}{llll}
\hline Boyut & Alt Boyutlar & Maddeler & $\begin{array}{c}\text { Cronbach alfa güvenirlik } \\
\text { katsayısı }\end{array}$ \\
\hline Öz yeterlik & Öz yeterlik & $1,2,3,4,5,6$ & .86 \\
\hline \multirow{3}{*}{ Endişe } & Bilgi ve değerlendirme & $7,8,9,10,11,12,13,14$ & .90 \\
& Yönetim & $15,16,17,18$ & .86 \\
& Sonuç ve yeniden odaklanma & $19,20,21,22,23,24,25$ & .83 \\
\hline
\end{tabular}

\section{Doğrulayıcı Faktör Analizi Bulguları}

$\mathrm{Bu}$ analiz, açımlayıcı faktör analizi sonucunda ortaya çıkan yapının ne derece uygun olduğunu belirlemek amacıyla kullanılmaktadır. Öncelikle ölçeğin özgün halindeki yapısının ne derece uygun olduğunu test etmek için doğrulayıcı faktör analizi yapılmıştır. Ancak, analiz sonuçları bir model ortaya koyamamıştır. $\mathrm{Bu}$ sebeple, faktör analizi sonucunda ortaya çıkan yapının uygunluğunu test etmek amacıyla doğrulayıcı faktör analizi yapılmıştır. Bu analizin uygulanmas1 sonucu hesaplanan indeks değerleri sirasıly $\chi^{2}=650.56, \mathrm{sd}=269 \mathrm{RMR}=0.05, \mathrm{RMSEA}=0.081$, $\mathrm{SRMR}=0.059$, GFI $=0.86$., $\mathrm{AGFI}=0.82, \mathrm{CFI}=0.87$ olarak belirlenmiştir. $\mathrm{Bu}$ analizin uygulanması sonucu, ki-kare değerinin serbestlik derecesine oranı $\chi^{2} / \mathrm{sd}=2.4 \quad\left(\chi^{2}=650.56 \mathrm{sd}=269\right)$ olarak hesaplanmıştır. Ancak, modifikasyon indeksi değerleri incelendiğinde, 2-1, 6-4 ve 11-10. maddeler arasında korelasyonun yeniden kontrol edilmiştir. Madde çiftleri arasında gözlenen hata korelasyonları dahil edilerek model yeniden incelenmiştir (Bakınız Şekil 1).

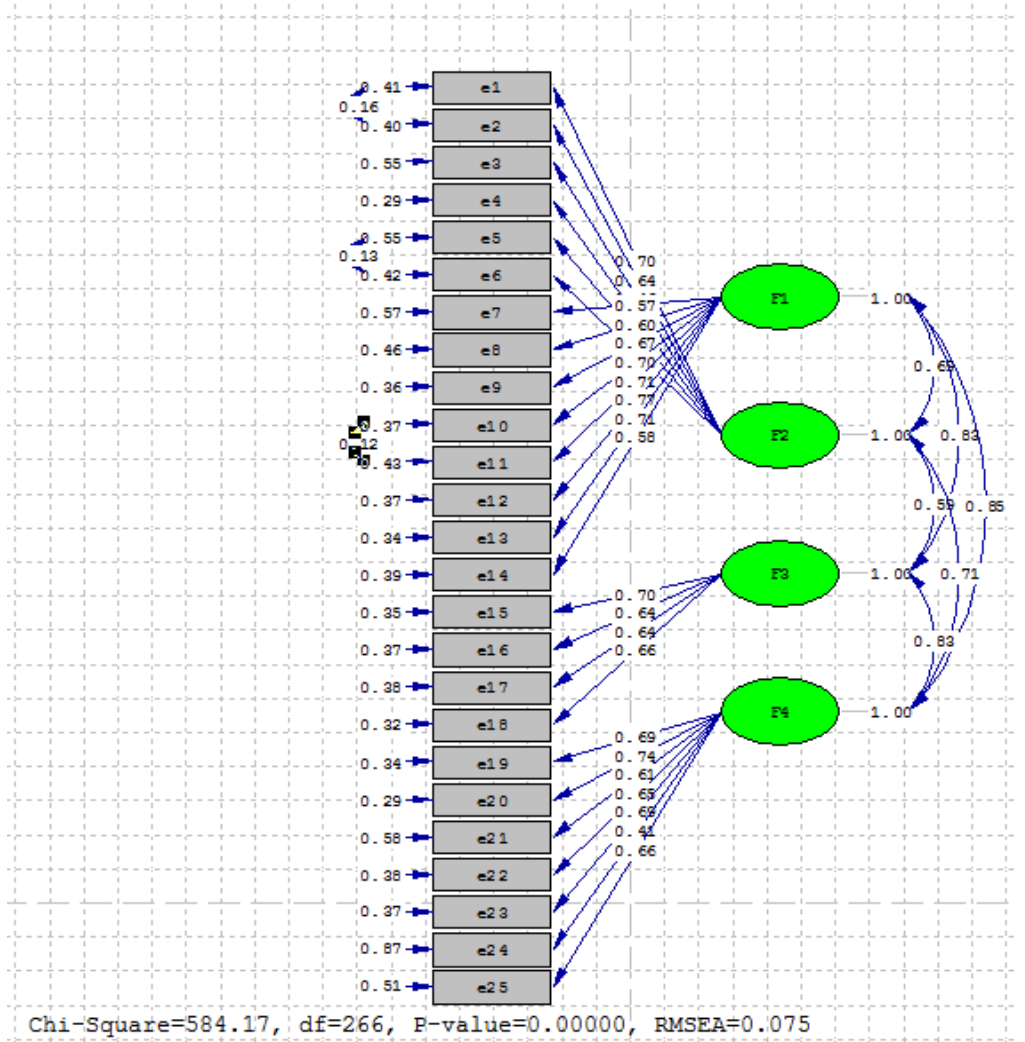

Şekil 1. Doğrulayıcı faktör analizi (DFA) sonuçları.

Analiz sonucu hesaplanan indeks değerleri sirasıyla $\chi^{2}=584.17, \mathrm{sd}=266, \mathrm{RMR}=0.05, \mathrm{RMSEA}=0.075$, $\mathrm{SRMR}=0.059$, GFI $=0.86$., AGFI $=0.82, \mathrm{CFI}=0.87$ 'dir. Ki-kare değerinin serbestlik derecesine oranı $\chi^{2} / \mathrm{sd}=2.1$ 'dir. Araştırmalar hesaplanan bu değerin 5 'ten küçük oluşu modelin kabul edilebilir uyum gösterdiği şeklinde kabul edilmektedir (Kline, 2016; Sümer, 2000). Bu çalışmada RMSEA indeks değerinin .05 ve .10 aralığında oluşu kabul edilebilir uyum olarak yorumlanmaktadır (Browne \& Cudeck, 1992; MacCallum, Browne, \& Sagawara, 1996). GFI ve AGFI indeks değerlerinin .80 'den büyük oluşu modelin kabul edilebilir düzeyde uyum gösterdiği şeklinde yorumlanmaktadır (Büyüköztürk, Akgün, Kahveci, \& Demirel, 2004; Cole, 1987). SRMR indeks değerinin .08'den küçük oluşu (Hu \& Bentler, 1999) modelle veri uyumun güçlü olduğu şeklinde yorumlanmaktadır. 


\section{Tartışma}

$\mathrm{Bu}$ araştırma kapsamında ölçeğin uyarlama sürecinde geçerlik ve güvenirlik çalışmaları yapılmıştır. Geçerlik çalışmasında uygulanan açımlayıcı faktör analizi ölçeğin dört faktörlü bir yapıya sahip olduğunu ortaya koymuştur. Uyarlanan ölçek öz yeterlik, bilgi ve değerlendirme, yönetim ile sonuç ve yeniden odaklanma olmak üzere dört alt boyuttan oluşmaktadır. Uyarlama çalışması yapılan ölçeğin öz yeterlik alt boyutu özgün haliyle aynı yapıyı korumuştur. Ancak, uyarlanan ölçeğin endişeyle ilgili kısmında yer alan alt boyutların özgün halinden farklı bir yapı oluşturduğu belirlenmiştir. Özgün ölçekte endişeye ilişkin beş alt boyuttan (bilgi, değerlendirme, yönetim, sonuç, yeniden odaklanma) oluşmasına rağmen uyarlanan halinde bilgi ve değerlendirme ile sonuç ve yeniden odaklanma alt boyutlarının kesiştiği görülmektedir. Bu durum öğretmen yetiştirme programlarında öğrenim gören ve bu çalışmaya katılan öğretmen adaylarının endişe düzeylerinin özgün ölçeğin geliştirilme sürecine katılan öğretmenlerden farklı olduğu şeklinde yorumlanabilir. Uyarlanan ölçek için hesaplanan güvenirlik katsayısı .94 olarak hesaplanmıştır. Field (2005) bu değerin .7 ve üzerinde oluşunu kabul edilebilir bir değer olarak göstermektedir. Güvenirlik çalışması kapsamında yapılan test tekrar test çalışmasında hesaplanan Pearson korelasyon katsayıs1 .894, p=.001 düzeyinde anlamlı bulunmuştur. Açımlayıcı faktör analizinden ortaya çıkan yapının ne derece uygun olduğunu belirlemek amacıyla uygulanan doğrulayıcı faktör analizi sonuçlarının kabul edilebilir düzeyde olduğu belirlenmiştir. Uyarlama çalışması yapılan ölçek Türk kültüründe kullanılabilecek geçerli ve güvenilir bir ölçme aracıdır.

\section{Sonuç}

$\mathrm{Bu}$ araştırma kapsamında öğretmen adayları için FeTeMM eğitimi hakkında öz yeterlik ve kaygı ölçeğinin geçerlik ve güvenirlik çalışması yapılmıştır. Uyarlama çalışması yapılan ölçeğin özgün halinden farklı bir yap1 oluşturduğu belirlenmiştir. Bu çalışmanın bir sonraki adımı olarak, Fen Teknoloji Mühendislik ve Matematik-Sanat (FeTeMM-S) ve sosyal bilimler için FeTeMM uygulamaları kapsamında öğretmen adaylarının öz yeterlik ve endişe düzeylerinin incelenmesi amacıyla ölçme aracının uyarlama çalışması yapılabilir. Buna ek olarak, FeTeMM eğitimi kapsamında öğretmenlerin (sınıf, fen bilgisi, matematik vb.) öz yeterlik ve endişe düzeylerini incelemek amacıyla ölçme aracının Türkçeye uyarlama çalışması yapılabilir. 


\section{Kaynakça / References}

Anılan, B., Görgülü, A., \& Balbağ, M. Z. (2009). Öğretmen adaylarının kimya laboratuvar endişeleri. E-Journal of New World Sciences Academy, 4(2), 575-594.

Bandura, A. (1986). Social foundations of thought and action: A social cognitive theory. Englewood Cliffs, NJ: Prentice-Hall.

Bandura, A. (1991). Social cognitive theory of self-regulation. Organizational Behavior and Human Decision Processes, 50, 248287.

Bandura, A. (1997). Self-efficacy: the exercise of control. New York, NY: Freeman.

Berlin, D. F., \& White, A. L. (2010). Preservice mathematics and science teachers in an integrated teacher preparation program for grades 7-12: A 3-year study of attitudes and perceptions related to integration. International Journal of Science and Mathematics Education, 8, 97-115.

Browne, M. W., \& Cudeck, R. (1992). Alternative ways of assessing model fit. Sociological Methods and Research, 21, $230-258$.

Buyruk, B., \& Korkmaz, Ö. (2016). FeTeMM Farkındalık Ölçeği (FFÖ): Geçerlik ve güvenirlik çalışması. Türk Fen Ĕ̆itimi Dergisi, 13(2), 61-76.

Büyüköztürk, Ş., Akgün, O. E., Kahveci, O., \& Demirel, F. (2004). Güdülenme ve Öğrenme Stratejileri Ölçeğinin Türkçe formunun geçerlik ve güvenilirlik çalışması. Kuram ve Uygulamada Ĕ̈itim Bilimleri, 4(2), 210-239.

Canbazoğlu, H. B., \& Tümkaya, S. (2020). İlkokul dördüncü sınıf öğrencilerinin fen, teknoloji, mühendislik, matematik (FeTeMM) tutumlarının çeşitli değişkenler açısından değerlendirilmesi. Türk Bilgisayar ve Matematik Eğitimi Dergisi, 11(1), 188-209.

Cattell, R. (1978). The scientific use of factor analysis. New York, NY: Plenum.

Charalambous, C. Y., \& Philippou, G. N. (2010). Teachers' concerns and efficacy beliefs about implementing a mathematics curriculum reform: Integrating two lines of inquiry. Educational Studies in Mathematics, 75, 1-21.

Cheung, D. (2002). Refining a stage model for studying teacher concerns about educational innovations. Australian Journal of Education, 46(3), 305-322.

Cheung, D., Hattie, J., \& Ng, D. (2001). Reexamining the stages of Concern Questionnaire: A test of alternative models. Journal of Educational Research, 94(4), 226-236.

Cole, D. A. (1987). Utility of confirmatory factor analysis in test validation research. Journal of Consulting and Clinical Psychology, 55(4), 584-594.

Çevik, M. (2018). Investigating STEM semantics and perceptions of engineer candidates and pre-service teachers: A mixed method sudy. International Journal of Educational Technology, 5(2), 1-18.

Derin, G., Aydın, E., \& Kırkıç, K. A. (2017). STEM (Fen-Teknoloji-Mühendislik-Matematik) Eğitimi Tutum Ölçeği. El-Cezeri Fen ve Mühendislik Dergisi, 4(3), 547-559.

Dinçer, A., \& Bikmaz, F. (2020). "What concerns pre-service teachers the most?": A quantitative research for concurrent and consecutive teacher training models. Teachers and Curriculum, 20(1), 63-72.

Field, A. (2005). Discovering statistics using SPSS. Thousand Oaks, CA: Sage.

Friday Institute for Educational Innovation. (2012). Teacher Efficacy and Attitudes Toward STEM Survey. Raleigh, NC: Friday Institute for Educational Innovation.

Fuller, F. F. (1969). Concerns of teachers: A developmental conceptualization. American Educational Research Journal, 6, 207226.

Gelen, B., Akçay, B., Tiryaki, A., \& Benek, İ. (2019). Fen bilimleri öğretmen adaylarının Fen-Teknoloji-Mühendislik-Matematik (FeTeMM)'e Yönelik Özyeterlik Ölçeği: Türkçe'ye uyarlama, geçerlik ve güvenirlik çalışması. Eğitimde Kuram ve Uygulama, 15(1), 88-107. 
Gene, H. E., George, A. A., \& Stiegelbauer, S. M. (2013). Measuring implementation in schools: The stages of Concern Questionnaire. Austin, TX: SEDL.

Geng, J., Jong, M. S. Y., \& Chai, C. S. (2019). Hong Kong teachers' self-efficacy and concerns about STEM education. The AsiaPacific Education Researcher, 28(1), 35-45.

Ghaith, G. M., \& Shaaban, K. (1999). The relationship between perception of teaching concerns, teacher efficacy, and selected teacher characteristics. Teaching and Teacher Education, 15(5), 488-496.

Güven, N. A., \& Akçay, H. (2012). Kimya öğretmen adaylarının öz yeterlik inançlarının farklı değişkenler açısından incelenmesi: Dokuz Eylül Üniversitesi örneği. Kuram ve Uygulamada Eğitim Bilimleri, 12(3), 2195-2216.

Hacıömeroğlu, G. (2018). Sınıf öğretmeni adaylarının fen, teknoloji, mühendislik ve matematik (FeTeMM) öğretim yönelim düzeylerinin incelenmesi. International Online Journal of Educational Sciences, 10(1), 183-194.

Hacıömeroğlu, G., \& Bulut, A. S. (2016). Öğretmen Adaylarının Entegre FeTeMM Öğretimi Yönelim Ölçeği Türkçe formunun geçerlik ve güvenirlik Çalışması. Eğitimde Kuram ve Uygulama, 12(2), 654-669.

Hair, J. F., Black, W. C., Tatham, R. L., \& Anderson, R. E. (2010). Multivariate data analysis. Upper Saddle River, NJ: Prentice Hall.

Hall, G. E., George, A. A., \& Rutherford, W. L. (1977). Measuring stages of concern about the innovation: A manual for use of the SoC questionnaire. Austin, TX: Southwest Educational Development Laboratory.

Hao, Y., \& Lee, K. S. (2016). Teaching in flipped classrooms: Exploring pre-service teachers' concerns. Computers in Human Behavior, 57, 250-260.

Hattie, J., \& Timperley, H. (2007). The power of feedback. Review of Educational Research, 77, 81-112.

Hoy, W. K., \& Woolfolk, A. E. (1990). Socialization of student teachers. American Educational Research Journal, 93, $279-300$.

Hu, L. T., \& Bentler, P. M. (1999). Cut-off criteria for fit indexes in covariance structure analysis: Conventional criteria versus new alternatives. Structural Equation Modeling, 6(1), 1-55.

İnançlı, E., \& Timur, B. (2018). Fen bilimleri öğretmen ve öğretmen adaylarının STEM eğitimi hakkındaki görüşleri. Uluslararası Eğitim ve Bilim Dergisi, 1(1), 48-68.

Karasar, N. (2010). Bilimsel araştırma yöntemleri. Ankara: Nobel.

Kızılay, E. (2017). STEM Semantik Farklılık Ölçeği'nin Türkçeye uyarlanması. The Journal of Academic Social Science Studies, $58(2), 131-144$.

Kitsantas, A., Zimmerman, B., \& Cleary, T. (2000). The role of observation and emulation in the development of athletic selfregulation. Journal of Educational Psychology, 91, 241-250.

Klein, P. (1986). A handbook of test construction. London: Routledge.

Kline, R. B. (2016). Principles and practice of structural equation modeling. New York, NY: The Guilford Press.

Knezek, G., \& Christensen, R. (2008). STEM Semantics Survey. Access: http://iittl.unt.edu/sites/default/files/ST EMSemanticssurvey.pdf

Lin, K. Y., \& Williams, P. J. (2016). Taiwanese preservice teachers' science, technology, engineering, and mathematics teaching intention. International Journal of Science and Mathematics Education, 14, 1021- 1036.

MacCallum, R. C., Browne, M. W., \& Sugawara, H. M. (1996). Power analysis and determination of sample size for covariance structure modeling. Psychological Methods, 1, 130-149.

McKinney, M., Sexton, T., \& Meyerson, M. J. (1999). Validating the efficacy-based change model. Teaching and Teacher Education, 15, 471-485.

Montgomery, A., \& Mirenda, P. (2014). Teachers' self-efficacy, sentiments, atitudes, and concerns about the inclusion of students with developmental disabilities. Exceptionality Education International, 24, 18-32. 
Morris, D. B., Usher, E. L., \& Chen, J. A. (2017). Reconceptualizing the sources of teaching self-efficacy: A critical review of emerging literature. Educational Psychology Review 29, 795-833.

Moseley, C., Reinke, K., \& Bookour, V. (2003). The effect of teaching outdoor environment education on elementary pre-service teachers' self-efficacy. Journal of Elementary Science, 15(1), 1-14.

Mulholland, J., \& Wallace, J. (2001). Teacher induction and elementary science teaching: enhancing self- efficacy. Teaching and Teacher Education, 17, 243-261.

Newlove, B. W., \& Hall, G. E. (1976). A manual for assessing open-ended statements of concern about an innovation, Austin, TX: Research and Development Center for Teacher Education, The University of Texas.

Pendergast, D., Garvis, S., \& Keogh, J. (2011). Pre-service student-teacher self-efficacy beliefs: An insight into the making of teachers. Australian Journal of Teacher Education, 36(12), 46-57.

Pul, H. H., \& Aksu, H. H. (2020). Sınıf öğretmenleri ve ile sınıf öğretmeni adaylarının matematik öğretimine yönelik öz yeterlilik inançları. Eğitim Kuram ve Uygulama Araştırmaları Dergisi, 6(1), 99-114.

Seçkin, M., \& Yılmaz, S. (2014). Örnek olay yönteminin öğretmen adaylarının kimya laboratuvarı dersine karşı endişelerine etkisi. Hacettepe Üniversitesi Ĕ̈itim Fakültesi Dergisi, 29(2), 215-227.

Schunk, D. H. (1984). Sequential attributional feedback and children's achievement behaviors. Journal of Educational Psychology, 76, 1159-1169.

Schunk, D. H., \& Hanson, A. R. (1989). Influence of peer-model attributes on children's beliefs and learning. Journal of Educational Psychology, 81, 431-434.

Smith, L. F., Corkery, G., Buckley, J., \& Calvert, A. (2012). Changes in secondary school pre-service teachers' concerns about teaching in New Zealand. Journal of Teacher Education, 64, 60-74.

Sümer, N. (2000). Yapısal eşitlik modelleri: Temel kavramlar ve örnek uygulamalar. Türk Psikoloji Yazılarl, 3(6), $49-74$.

Tavşancıl, E. (2002), Tutumların ölçülmesi ve SPSS ile veri analizi, Ankara: Nobel.

Timur, B., \& Belek, F. (2020). FeTeMM etkinliklerinin öğretmen adaylarının öz-yeterlik inançlarına ve FeTeMM eğitimi yönelimlerine etkisinin incelenmesi. Pamukkale Üniversitesi Ĕ̆itim Fakültesi Dergisi, 50, 315-332.

Tschannen-Moran, M., \& Woolfolk-Hoy, A. W. (2001). Teacher efficacy: Capturing an elusive construct. Teaching and Teacher Education, 17(7), 783-805.

Tschannen-Moran, M., \& Woolfolk-Hoy, A. (2007). The differential antecedents of self-efficacy beliefs of novice and experienced teachers. Teaching and Teacher Education, 23, 944-956.

Tschannen-Moran, M., Woolfolk-Hoy, A., \& Hoy, W. K. (1998). Teacher efficacy: Its meaning and measure. Review of Educational Research, 68, 202-248.

Usher, E. L., \& Pajares, F. (2008). Sources of self-efficacy in school: Critical review of the literature and future directions. Review of Educational Research, 78, 751-796.

Wenner, G. (2001). Science and mathematics efficacy beliefs held by practicing and prospective teachers: A five year perspective. Journal of Science Education and Technology, 10, 181-187.

Woolfolk-Hoy, A. E. (2000). Changes in teacher efficacy during the early years of teaching. The Annual Meeting of the American Educational Research Association, New Orleans.

Yaman, C., Özdemir, A., \& Vural, R. A. (2018). STEM Uygulamaları Öğretmen Öz-Yeterlik Ölçeğinin geliştirilmesi: Bir geçerlik ve güvenirlik çalışması. Adnan Menderes Üniversitesi Sosyal Bilimler Enstitüsü Dergisi, 5(2), 93-104. 
Ek 1: Türkçeye Uyarlanan Öğretmen Adayları için FeTeMM Eğitimi Hakkında Öz yeterlik ve Endişe Ölçeği

1.İyi bir FeTeMM dersi hazırlamak için kendime güvenirim.

2. FeTeMM dersimi hazırlarken karşıma çıkabilecek problemleri çözmenin yolunu biliyorum.

3. FeTeMM öğretim etkinliklerini yürütmenin zor olmadığını düşünüyorum.

4. FeTeMM eğitim derslerinde güçlüklerin üstesinden gelmekte kendime güvenirim.

5. FeTeMM eğitimini staj okulumda nasıl yürüteceğimi biliyorum.

6. Geçmiş öğretim deneyimlerim FeTeMM eğitimi için uygun bir çözüm sağlayabilir.

7. Öğrencilerimin FeTeMM eğitimini kabul etmek isteyip istemediklerini önemserim.

8. FeTeMM öğretimimi geliştirilmemde, düzenleyen olarak benim rolüm hakkında daha fazla şey öğrenmeyi umuyorum.

9. Öğrencilerin FeTeMM eğitimine karşı tutum ve cevaplarını önemsiyorum.

10. Diğer öğretmenlerin FeTeMM eğitimi deneyimlerinden öğrenmeyi umuyorum.

11. Öğrencilerin FeTeMM eğitimi öğrenme performanslarını nasıl değerlendireceğim hakkında daha fazla şey öğrenmeyi umuyorum.

12. FeTeMM öğretiminin verimli şekilde nasıl yapılacağı hakkında daha fazla bilgi sahibi olmayı umuyorum.

13. Tecrübeleri paylaşmak ve iş birliği yapmak için diğer FeTeMM öğretmenleriyle arkadaş olmayı umuyorum.

14. FeTeMM pedagojik yaklaşımlarını (öğretim teknik ve stratejilerini) bütünleştirmenin yolunu bilmeyi umuyorum.

15. FeTeMM öğretimini yerine getirirken iş yükü hakkında daha fazla şey öğrenmeyi umuyorum.

16. FeTeMM eğitimini uygularken, insanlarla ve diğer yönetim sorunlarıyla ilgili olarak iş birliği yapmak için çok zaman ve enerji harcamam gerekip gerekmediğini merak ediyorum.

17. FeTeMM dersi verirken akademik olmayan diğer konularda (kişisel işler, sorumluluklar) daha fazla zamana ihtiyacım olup olmadığını merak ediyorum.

18. FeTeMM faaliyetlerini gerçekleştirmek için yeterli ders saati bulunup bulunmadığını merak ediyorum.

19. FeTeMM eğitimini tanıtmanın öğrenciler üzerindeki etkisini önemsiyorum.

20. Öğrencilerin öğrenme deneyimlerine bağlı olarak FeTeMM pedagojik yaklaşımlarını (öğretim teknik ve stratejilerini) en iyi şekilde kullanmayı umuyorum.

21. FeTeMM eğitiminin Millî Eğitim Bakanlı̆̆ı tarafından desteklenmesini önemserim.

22. Takip edebileceğim önerilen FeTeMM öğretim kaynakları olup olmadığını bilmek isterim.

23. FeTeMM öğretim etkinliklerini kendi deneyimlerime dayanarak en iyi şekilde kullanmayı umuyorum.

24. Mevcut FeTeMM yaklaşımlarımdan daha iyi olan diğer pedagojik yaklaşımları (öğretim teknik ve stratejilerini) biliyorum.

25. Öğrencilerin ilgilerini uyandırmak ve FeTeMM eğitimindeki rolleri hakkında bilgi vermek için istekliyim. 